\title{
Situation of Sectors Financed by Participation Banks: 2015- 2019 Period Analysis
}

\author{
Katılım Bankacılı̆̆ı Tarafindan Finanse Edilen Sektörlerin Durumu: 2015-2019 \\ Dönemi Analizi \\ Ümit GÜCENME GENÇOĞLU * \\ Alp $A Y T A C$ *** \\ Süleyman Hakkı AYHAN ***
}

\begin{abstract}
Participation Banks refers to the organizations that operate with the principle of collecting funds and extending loans through special current and participation accounts and the branches in Turkey of such organizations established abroad. The main aim of this research is to shed light on which sectors are financed by participation banks. To accomplish this aim, data covering the 2015-2019 period is used in this research. State-funded participation banks such as Vakif and Ziraat established in 2015 is the reason why authors examined the 2015-2019 period. Data was downloaded from the Participation Banks Association of Turkey website, and it is prepared at the end of 2019. In this study, situation analysis is used to show the development of participation banks and the sectors they finance. In this context, the growth in terms of the number of branches and personnel, the change in basic indicators, and the financed sectors' situation were determined in the examined period. Results show that participation banks have increased their role in the banking system. In addition, there is a relation between their growth and funding and fundraising levels. It is found that participation banks mainly finance construction sector which have an essential effect on the macroeconomic growth of the Turkish economy.
\end{abstract}

\section{KEYWORDS}

Participation Banks, Construction Sector, Situation Analysis, Interest-Free Banking, Financial Analysis

\section{$\ddot{O} Z$}

Katılım bankaları özel cari ve katılma hesapları yoluyla fon toplamak ve kredi kullandırmak esas olmak üzere faaliyet gösteren kuruluşlar ile yurtdlşında kurulu bu nitelikteki kuruluşların Türkiye'deki şubelerini ifade eder. Yapılan bu çalışmanın amacı, katılım bankaları tarafindan finanse edilen sektörlere ışık tutmaktır. Bu amacı gerçekleştirmek için 2015-2019 yıllarını kapsayan veriler kullanılmıştır. Çalışmada 2015-2019 döneminin alınmasının sebebi Vakıf Katılım ve Ziraat Katılım gibi devlet destekli katılım bankalarınin kuruluş yıllarınin 2015 olmasıdır. 2019 yll sonu itibariyle Türkiye Katılım Bankaları Birliği tarafindan hazırlanan veriler kullanılmıștır. Bu çalışmada katılım bankalarının 20152019 yılları arasında bankacılık sektörü içindeki gelişsimini göstermek ve katılım bankaları tarafindan finanse edilen sektörleri tespit etmek amacıyla durum analizi yapılmıştır. Bu kapsamda incelenen dönemde şube ve personel saylsı olarak geliş̧im, temel göstergelerdeki değişim ve finanse edilen sektörlerin durumu tespit edilmişstir. Sonuçlara göre, katılım bankaları, bankacllık sektöründeki rolünü artırmıştır. Ayrıca, katılım bankalarının büyümesi ve fon toplama/kullandırmaları arasında bir ilişki mevcuttur. Katılım bankaları, Türkiye'de makroekonomik gelişmeye önemli katkı veren inşaat sektörünü yoğun bir şekilde finanse etmektedir.

ANAHTAR KELIMELER

Katılım bankaları, Inşaat Sektörü, Durum Analizi, Faizsiz Bankacılık, Finansal Analiz

\begin{tabular}{|c|c|c|}
\hline & $\begin{array}{c}\text { Makale Geliş Tarihi / Submission Date } \\
\text { 31.07.2021 }\end{array}$ & $\begin{array}{c}\text { Makale Kabul Tarihi / Date of Acceptance } \\
\text { 23.09.2021 }\end{array}$ \\
\hline Attf & $\begin{array}{l}\text { Gücenme Gençoğlu, Ü., Aytaç, A. ve } \\
\text { 2015-2019 Period Analysis. Selcuk Ün }\end{array}$ & $\begin{array}{l}\text { Situation of Sectors Financed by Participation Banks: } \\
\text { er Meslek Yüksekokulu Dergisi, } 24 \text { (2), 453-462. }\end{array}$ \\
\hline
\end{tabular}

\footnotetext{
* Professor, Bursa Uludağ University Faculty of Economics and Administrative Sciences Department of Business Administration, umitgucenme@uludag.edu.tr, ORCID: 0000-0002-8034-9063

** Research Assistant, Bursa Uludağ University Faculty of Economics and Administrative Sciences Department of Business Administration, alpaytac@uludag.edu.tr, ORCID: 0000-0003-4949-4884

${ }^{* * *}$ Branch Manager of Albaraka Türk Participation Bank Yeniyol Bursa, suleymanhakki@ hotmail.com, ORCID: 0000-0003-2583-9139
} 


\section{INTRODUCTION}

Some societies in the world try to stay away from interest income due to specific sensitivities. For this reason, funds that do not go to conventional banks may remain idle. This situation can be considered as a loss both for the general economy and for the saver. That is why participation banks emerge as an innovation in the financial sector. The aim of participation banks is to bring funds that do not go to conventional banks due to interest rate sensitivity to the economy and help savers store and evaluate their funds safely. The aims of participation banks can be listed as follows:

- Utilization of idle funds,

- Ensuring capital inflow,

- Contribution to the development of real economy,

- Prevention of financial crisis and informal economy,

- Creating workforce,

- Preventing Waste of Resources.

Participation banks, formerly named private financial institutions, were established as an alternative to the traditional banking system in the 1980s. These institutions, which were established as "Special Finance Institution" in 1983 with the Decree of the Council of Ministers no. 83\7506, were renamed as "Participation Bank" in 2005 with the "Banking Law No.5411". Along with these developments, the title of the "Association of Special Finance Institutions," which was established in 2001 to ensure coordination between private financial institutions and take the sector further, was changed to the "Participation Banks Association of Turkey." When talking about participation banking it should be understood that institutions that do not generate profit or loss on nominal transactions, but provide financing for actual economic activities (trade and production activities) or directly carry out these activities and share the profit/loss resulting from these activities with their customers. Apart from the differences in fund collection and lending processes, these banks offer all other interest-free banking services (Tunç, 2010: 113). Based on Banking Law No.5411, "Participation Banks refers to the organizations that operate with the principle of collecting funds and extending loans through special current and participation accounts and the branches in Turkey of such organizations established abroad."

The beginning of the 1960s leads the development of an interest-free banking system in the world. At this time, oil prices were increased, which led to the economic development of the Middle East and Gulf countries. It is first known as interest-free banks, today known as Islamic and in Turkey, it is known as Participation banks. In 1963, the establishment of Islamic banking by Ahmad Al-Najjar in Egypt was the first successful establishment of this banking system. This bank sustained its activities until 1967, and after that, Islamic banks without interest continued to be opened in various parts of the world (Emeç, 2020: 84). The establishment of Dubai Islamic Bank (DIB), Islamic Development Bank in Jeddah, and the Accounting and Auditing Organization for Islamic Financial Institutions (AAOFI) in Bahrain was very effective in developing this banking system. In the following decade, the entry of traditional global large banks into the Islamic banking sector has made significant contributions to the development of the industry. In the 1980s, an economic decline began in the Arab world due to the decrease in oil revenues, the strengthening of the dollar, increased interest rates, and capital outflows from OPEC countries. Despite this, Arab banks opened in the United States, and interest-free banks were established in Pakistan, Iran, and Turkey.

With the establishment of the Istanbul Stock Exchange in 1983, liberalization in the financial market, and the abolition of the state's intervention, interest-free banking started to be served by private financial institutions for the first time in Turkey. "Private Financial Institution" name changed to "Participation Bank" with the Banking Law No. 5411 enacted in 2005. In particular, with the economic crisis in 2008, there has been a significant interest increase in interest-free financial institutions.

Participation banks collect savings that the traditional banking system cannot bring to the economy. While these funds brought into the market increase the savings, they also ensure more efficient use in the economy. As of traditional banking, participation banks have fundraising and funding methods as well.

Fundraising methods of participation banks are participation accounts and current private accounts. According to Banking Law No. 5411, "Special current accounts are accounts created by funds that are opened in participation banks and can be withdrawn partially or completely when desired, and that do not provide returns to the account holder." These are the equivalent of the deposit account concept in deposit banks. In other words, they are not dependent on maturity, and they can be taken back without any return/accrual whenever requested. According to Banking Law No. 5411, participation accounts are "the accounts that give the result of participation in the profit or loss arising from the use of the funds deposited in participation banks 
by these institutions, in return for which no predetermined return is paid to the account holder and the repayment of the principal is not guaranteed." Accordingly, unlike time deposits in deposit banks, there is a "profit-loss relationship" instead of a "debt-receivable relationship." When a deposit account is opened in traditional banking, the amount of interest paid to the account holder at the end of maturity is determined and committed to the account holder. In participation banks, there is neither a commitment to a return on maturity nor a principal guarantee for funds deposited to participate in profit and loss (Tunç, 2010:128). Maturity and participation in profit/loss are determined when these accounts are opened. The bank transfers the participation account from the account owner to TL, USD, and EUR pools according to the type and term of the money. The funds accumulated in the pools are used with specific methods. Profit or loss generated by fund utilization methods is transferred to relevant pools according to the type and maturity of the money. Profit/loss calculation is made, and it is shared in public opinion via mass media.

Funding methods of the participation banks are divided into two groups as non-cash and cash.

Giving a letter of guarantee, which is the use of non-cash funds, is a commitment by the bank, as a guarantee, to an act that the bank's customer has to perform against the counterparty with a different right and the receivable. Letter of credit, which is in the same group, is defined as the bank's contingent payment guarantee. This method provides the most benefit to the exporter. With the letter of credit, the exporter receives a guarantee for the payment with the bank's commitment and creates financing for itself (İyibozkurt, 2001:538).

Murabaha, one of the methods of using cash funds, is based on buying it in cash, adding a certain profit to it, and selling it at maturity. The customer negotiates with the seller of the goods over the cash price for the goods or services they want to buy. Then, it deals with the participation bank for the financing amount and requests that the relevant bank purchase that good or service in advance and sell it to her on a maturity basis. As a result of the agreement with the customer, the goods or services are purchased by the bank in advance and sold to the customer at a previously agreed amount.

The profit amounts other than the principal money in the repayments received from the customer are distributed to the participation account customers. Islamic Law discusses in detail the three forms of sale of the goods subject to sale. These selling methods are defined below (Udovitch, 2019:216):

- Tawlia is that the seller sells the goods at cost without putting any profit or loss,

- Wadiah is the sale of a good at a discount over its cost,

- Mudarabah is the sale of a good by adding a fixed profit or rate of profit to its cost price.

On the Mudarabah method, the labor-capital partnership, the bank puts all the required investment whereas the customer places the labor. The profit from the transaction is shared between the bank and the customer at the rates agreed at the beginning. When there is a loss, the bank takes over the loss if the customer does not have a fault (Bacha, 1997: 27-28).

Musharakah is a method in which individuals or institutions holding capital and labor together establish a partnership to realize any project. Collaboration starts with a contract between the participation bank and the entrepreneur (the project owner). Based on this contract, the bank and the entrepreneur agrees to finish a project or start a new one (Özsoy, 2012: 178). The participation bank joins the project only with capital, while the entrepreneur joins both with capital and labor. The profit is shared based on the contract made at the beginning. Before the profit distribution, the necessary cost to run the project is deducted from the gross profit. If there is a loss occurs, this is distributed based on the capital participation rate.

Ijarah, also known as leasing, is a contract between the tenant and the owner to use a property, which is generally a machine, for a certain period. Ijarah is the funding method of participation banks. In this system, the participation bank purchases the goods the customer needs and leases them for lease payments. At the end of the contract, the customer can own the property.

Alqard-Alhasan (lending money) is rarely used in case of necessity or for extraordinary reasons; participation banks provide financing to their customers without any gain or profit expectation. Trust is the main issue in this financing. In return for financing, there is nothing expected from the customer besides capital (Atar, 2020: 59).

Selem is defined as a purchase and sale transaction in which the payment is made in cash at the time of the contract, but the delivery of the goods is postponed until the previously determined date. The purchase of two tons of wheat to be delivered one year later while the fee is paid in advance may be an example (Al-Bashir and Al-Amine, 2020: 284).

In fulfilling the aim of participation banks, currently, six participation banks are operating in Turkey (https://tkbb.org.tr, 2019). These are Albaraka Participation Bank, Türkiye Emlak Participation Bank, Kuveyt Türk Participation Bank, Türkiye Finans Participation Bank, Vakıf Participation Bank, and Ziraat Participation 
Bank. This research aims to shed light on which sectors are financed by participation banks. In this study, situation analysis is used to show the development of participation banks and the sectors they finance. The authors tried to determine which sectors are financed by the participation banks and why it is vital for macroeconomic development. In addition, the authors try to enlighten the role of these banks in the banking sector and how they sustain their activities.

\section{METHODOLOGY AND FINDINGS}

The authors tried to shed light on which sectors are intensely financed by participation banks in this study. But first, the development of participation banks is introduced by highlighting its fundamental indicators over the five-year period. In addition, funding, fundraising, and financing types are explained to see the evolution of participation banks in the overall banking sector. The reason authors examined the 2015-2019 period is state-funded participation banks such as Vakıf, and Ziraat established in 2015. In this study, situation analysis is used to show the development of participation banks and the sectors they finance. In this context, the growth in terms of the number of branches and personnel, the change in basic indicators, and the financed sectors' situation were determined in the period examined.

In this research data was downloaded from the Participation Banks Association of Turkey website, and it is prepared at the end of 2019. Six participation banks are operating in Turkey. To highlight the current situation of the participation banking sector in Turkey below analysis is performed that covers the 2015-2019 period:

- Share of the participation banks in the overall banking sector,

- Fundraising and funding of participation banks over the years,

- Sectors financed by participation banks with cash and non-cash loans over the years.

Table 1 and Table 2 shed light on the development of participation banking over the five years. Table 1 shows that participation banks' total branch and personnel have increased, whereas these indicators have decreased in the overall banking sector. In detail, in 2015, only four participation banks were operating, whereas between 2016-2018, this number increased to 5. In 2019, another participation started operating. Increasement in participation banks causes the growth of total branch and personnel.

\section{Table 1: Total Branch and Personnel of Participation Banks and Overall Banking Sector}

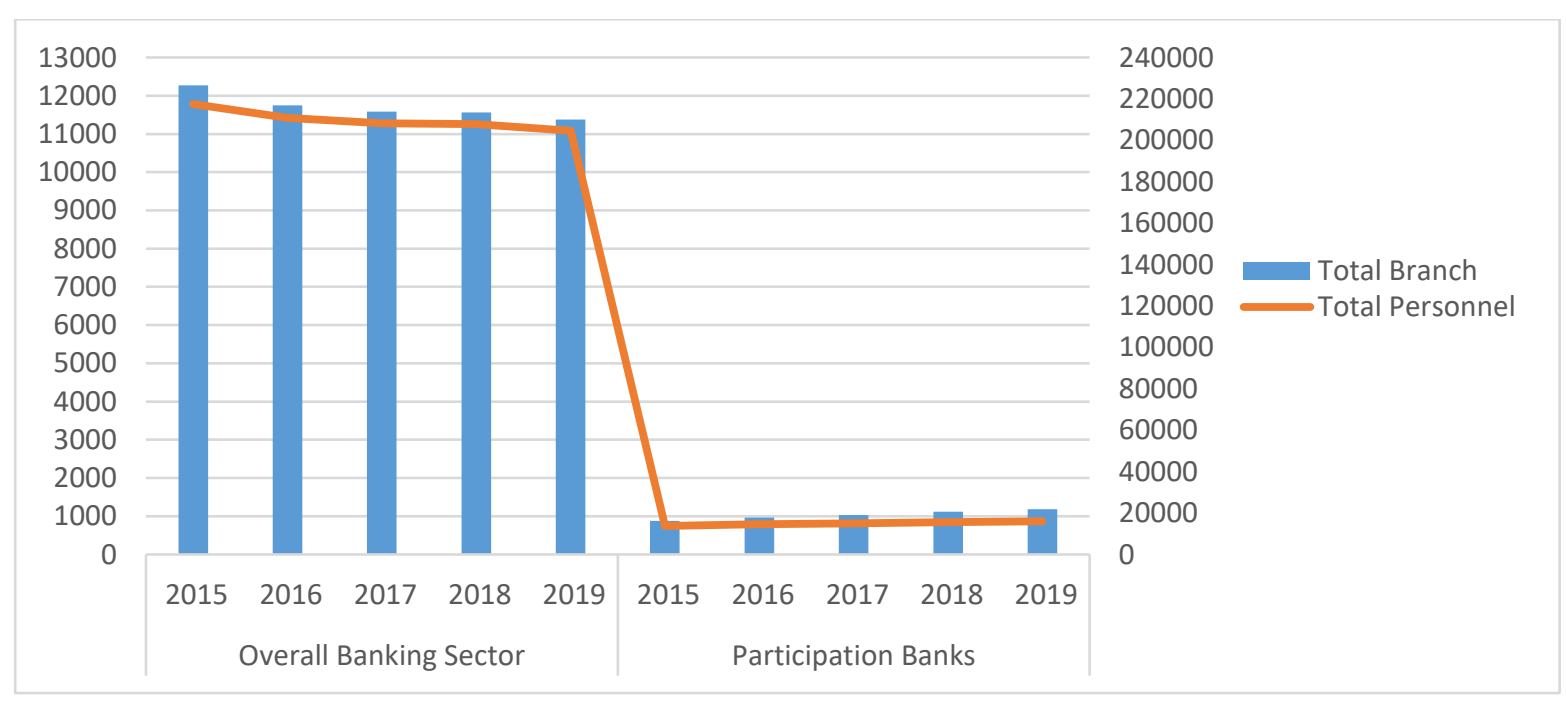

On Table 2, it can be seen that over the five year main indicators of participation banks such as total assets, loans, deposit, equities and net profit of participation banks has been increased. With this development, participation banks become a factor in the overall banking sector. Participation banks increased their services by increasing their branches and employees. This situation caused an increase in their fundamental indicators, and participation banks started to become an essential member of the sector. 


\section{Table 2: Main Indicators of Participation Banks}

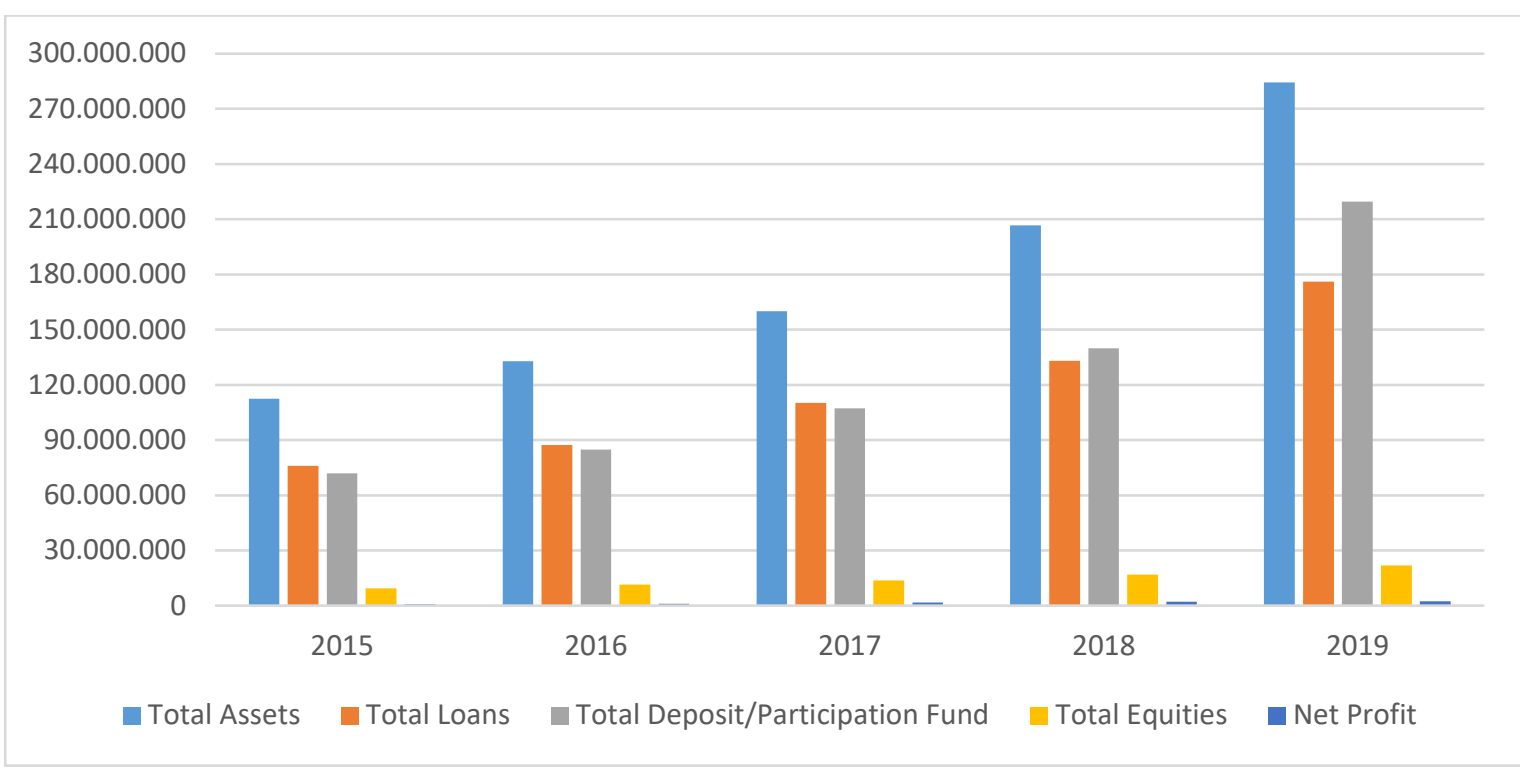

The increasing importance of participation banks in the sector can be seen from the changes in the data in Table 3 and Table 4. Fundraising of participation banks has been increased over the five-year. In detail, both the Turkish Lira and foreign currency have increased steadily. When comparing each other, fundraising based on foreign currency has grown faster than the Turkish Lira. Over the five-year, foreign currency fundraising growth average is $\% 42$, whereas the Turkish Lira average is $\% 25$.

Table 3: Fundraising of Participation Banks over 2015-2019 period

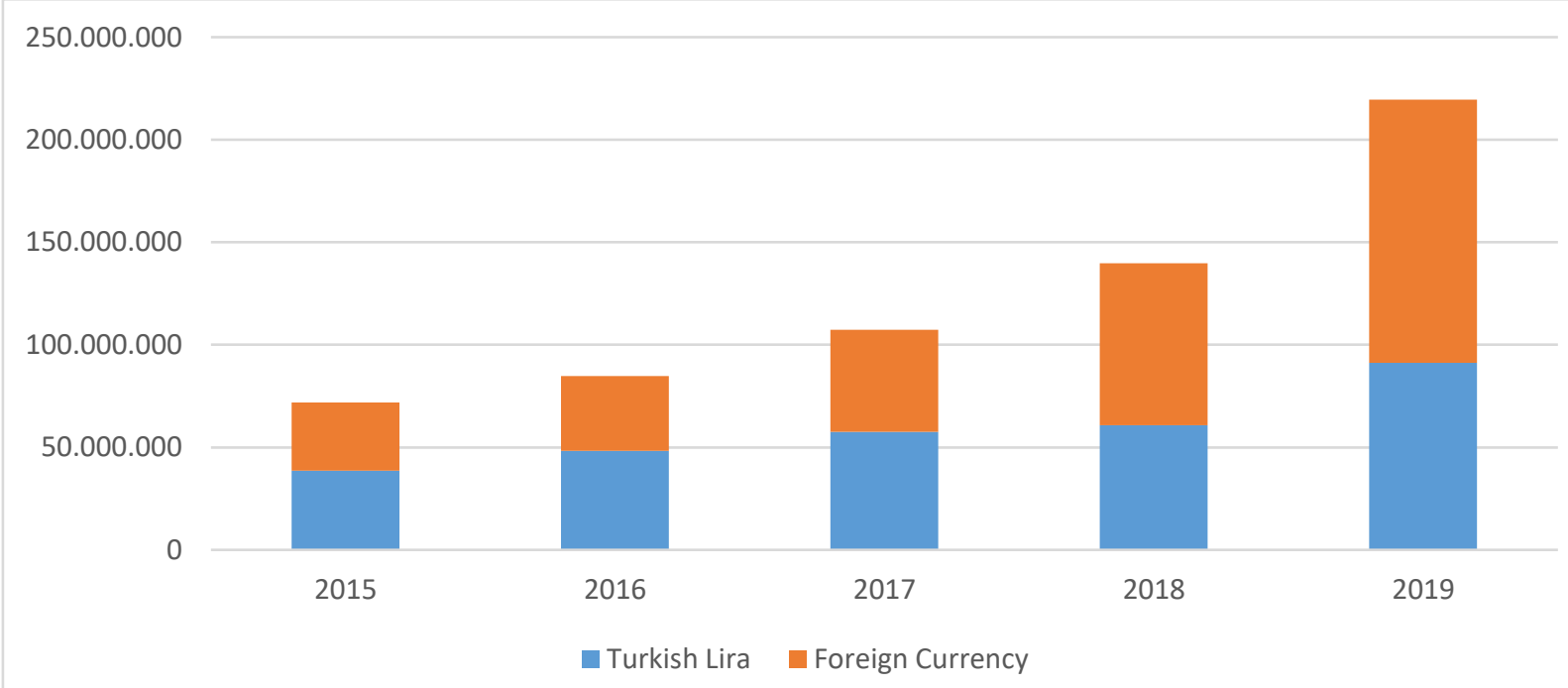

In Table 4, the funding course of participation banks over five-year can be seen. Funding is generally based on the Turkish Lira. In the examined period, funding has increased progressively, and the average growth of this course is $\% 24$. 
Table 4: Funding course of Participation Banks

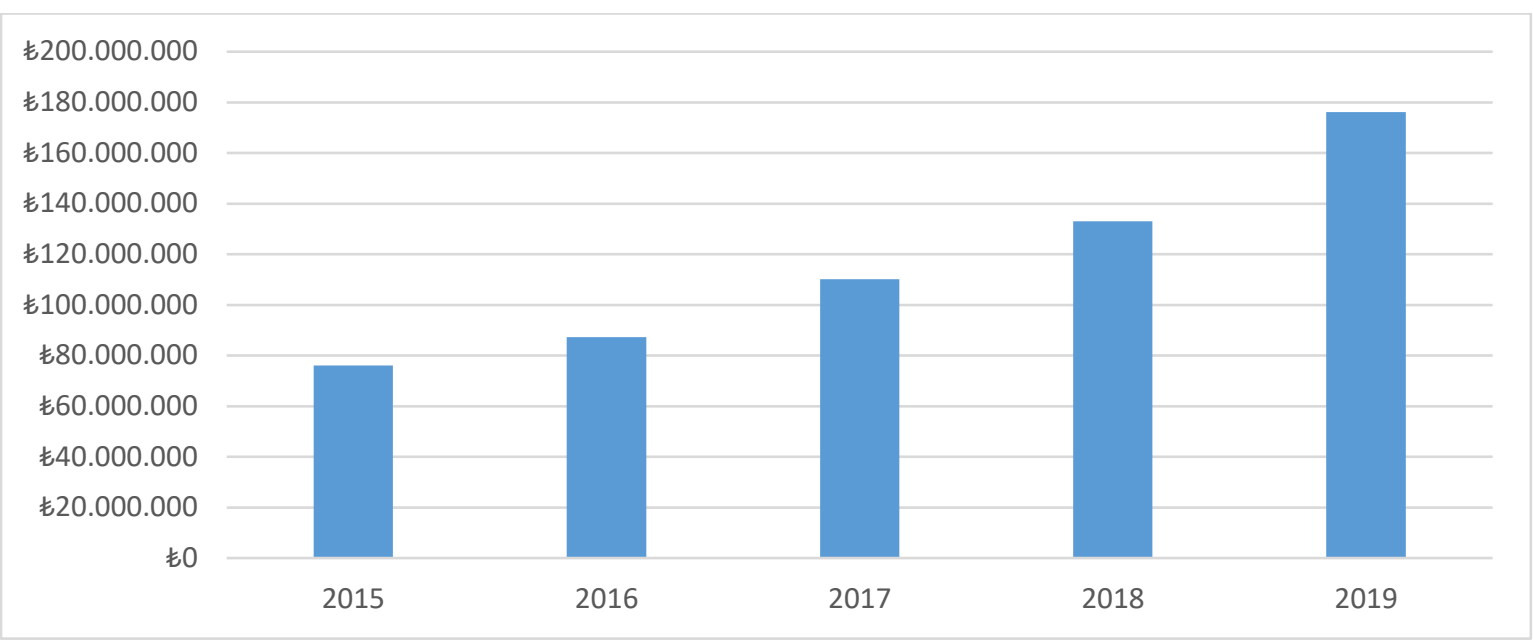

Financing types are an indicator of how participation banks add value to the macroeconomy. In addition, their distribution shows which sector contributes the most to this growth. Table 5 and Table 6 show that business loans are the most used financing types of participation banks. Every year, participation banks expand their business loans. In 2018, business loans' share in total exceeded \%60. Consumer loans follow this sector.

Table 5: Financing Types of Participation Banks (TL based)

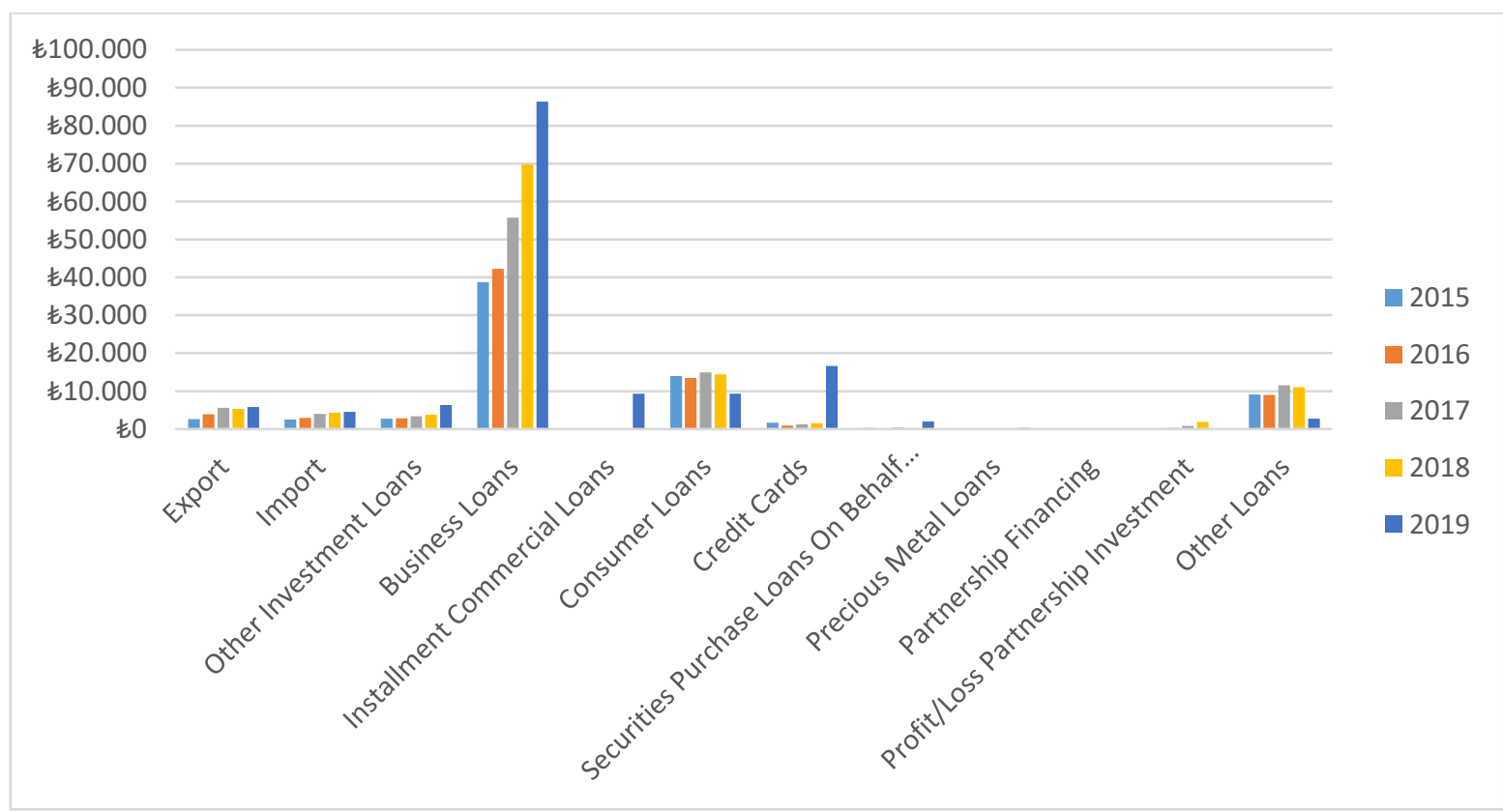


Table 6: Financing Types Distribution of Participation Banks

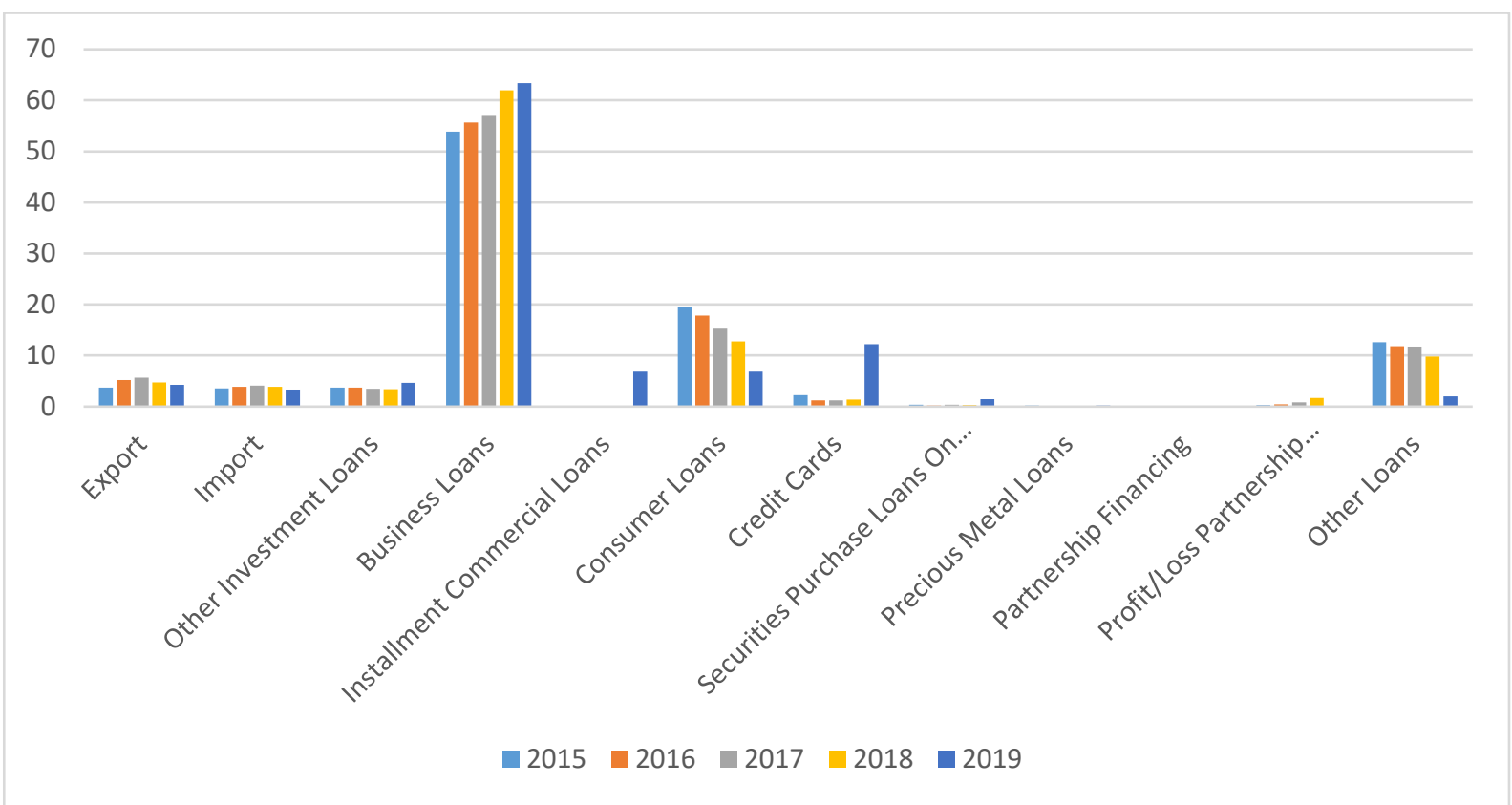

The main aim of this research is to shed light, which sectors are financed by participation banks. Tables 7 and 8 shows that construction is the leading sector financed by participation banks. Every year, the construction sector's funding opportunities and its share have increased. In 2019, the construction sector's funding exceeded 35 million Turkish Lira. When looking at its share, every year it is around \%35-40.

Table 7: Sectors Financed by Participation Banks

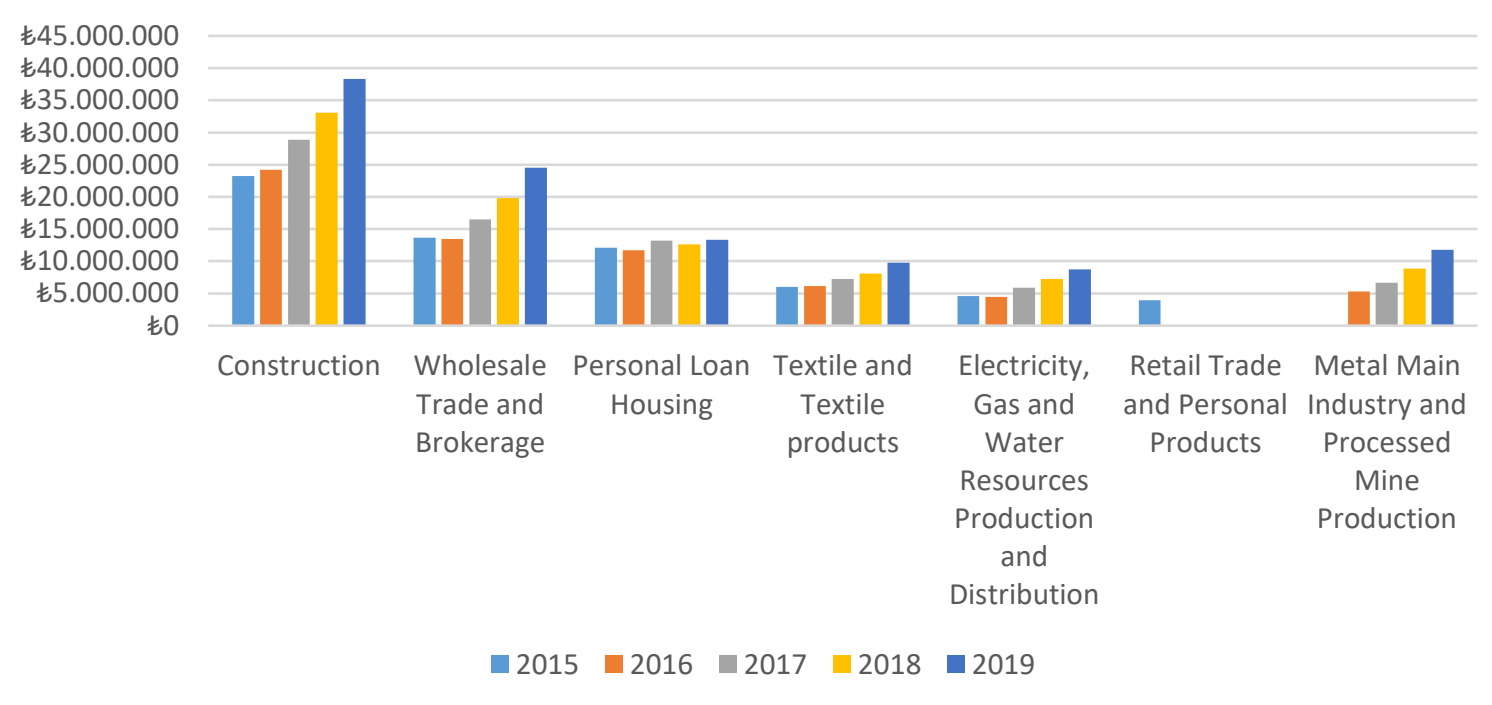


Table 8: Sectoral Distribution

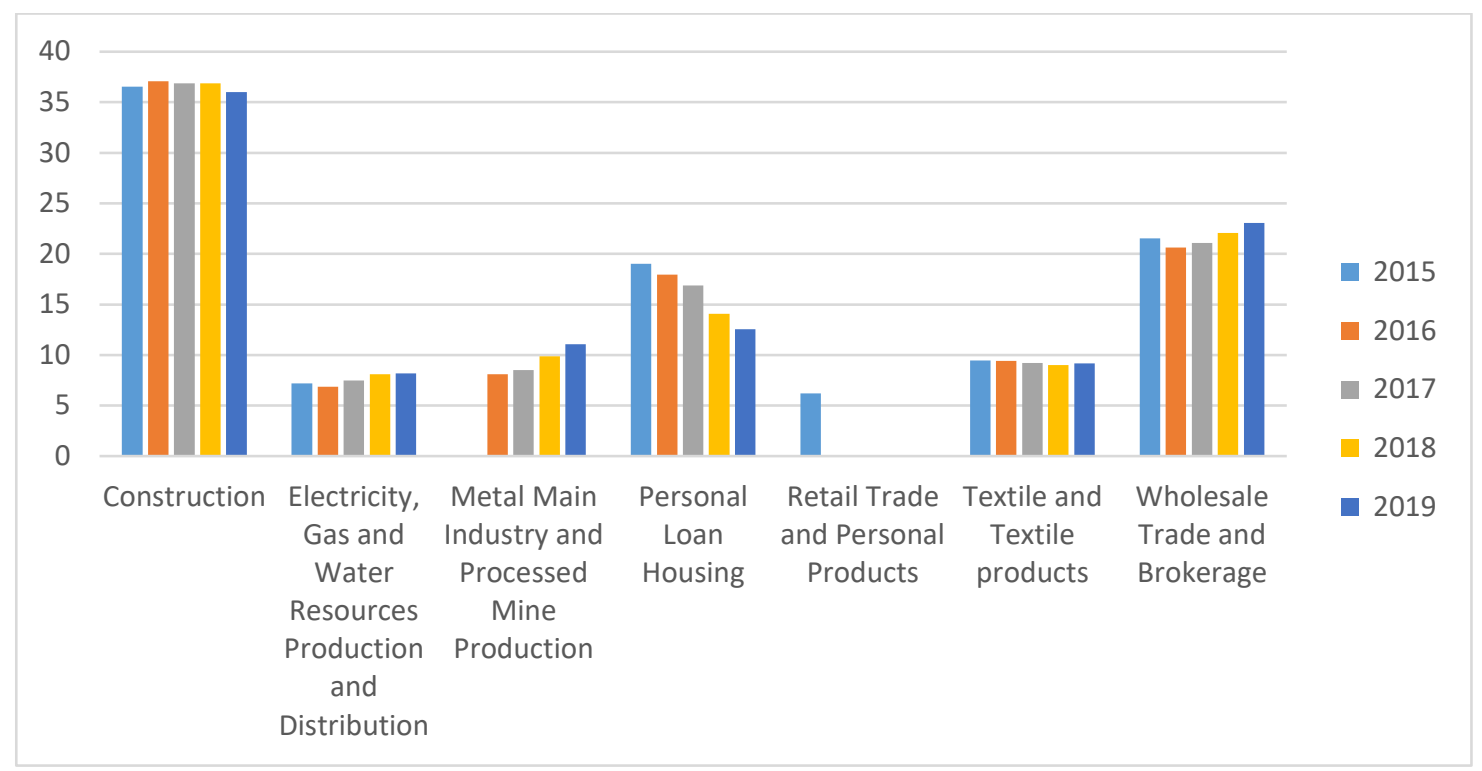

Construction is considered one of the leading sectors in the macroeconomic growth of the Turkish economy. The Central Bank of Turkey's published data about sectors (http://www3.tcmb.gov.tr) proves this fact. According to the data published in 2019 , the construction sector has a $16 \%$ share in the real sectors and employs 1.070.264 people. Fundamental indicators about this sector (Table 9) show that total assets, equities, and net sales increased significantly. Even though short-term liabilities increased every year, total assets' growth is bigger than short-term liabilities'. This situation shows that the construction sector has no difficulties with payment. In addition, a rise in the equities can be interpreted as more investors are looking at this sector. These indicators may shed light on why construction is the most financed sector by participation banks.

\section{Table 9: Key Indicators of Construction Sector}

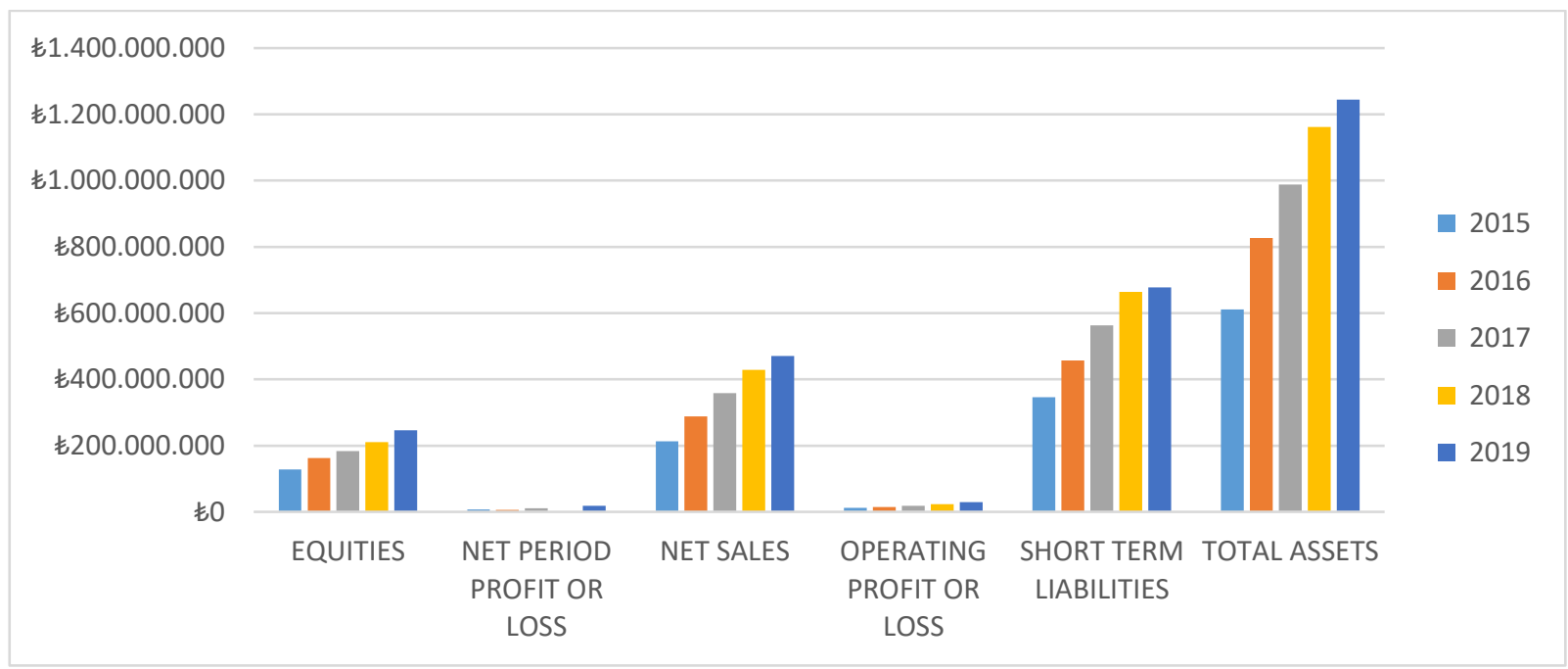

\section{RESULTS}

Some savers do not prefer interest income due to their beliefs or other reasons. Therefore, their savings becomes idle. Participation banks were established to bring these savers' funds to the economy. These banks have a say in the banking sector and will continue to develop in the following years. When compared with traditional banks, participation banks have different funding and fundraising methods.

Participation banks expand their funding and fundraising opportunities by increasing their branch and personnel between 2015-2019. Even though the banking sector's branch and personnel data fluctuate, participation banks' data have risen over the five-year period. 
Interest-free banking is getting more and more attention daily, and this fact is reflected in key indicators such as the increase of total assets, deposit/participation funds, and equities.

Between 2015-2019, business loans were by far the most used financing type (more than \%50), followed by consumer loans (around \%20). In detail, construction, wholesale trade and brokerage, and personal loan housing are intensely financed by participation banks in the five-year span. Although it seems to be at a low rate, participation banks' financing of "Electricity, Gas and Water Resources Production and Distribution" and "Metal Main Industry and Processed Mine Production" sectors has increased.

The Central Bank of the Republic of Turkey's published data demonstrates the importance of supporting the construction sector. This sector holds a \%16 share in the real economy and, its key indicators show the development of this sector. The total number of companies and this sector's employee volume is why this sector is mainly financed by participation banks over the analyzed period. 


\section{REFERENCES}

Al-Bashir, Muhammad and Al-Amine, Muhammad (2020) İslami Finansta Risk Yönetimi, (Çev. Ali Kürşat Sak - Dr. Gencay Karakaya), Albaraka Yayınları, İstanbul.

Atar, Abdülkadir (2020) Şeyhülislam Fetvaları Işı̆̆ında Osmanlı'da İktisadi Hayat, Albaraka Yayınları, İstanbul.

Bacha, Obiyathulla I. (1997) "Adapting Mudarabah Financing to Contemporary Realities: A proposed Financing Structure.”, Munich Personal RePEc Archive, 26-54.

Emeç, Ömer (2020) Yeni Dünya ve Yeni Finans, Albaraka Yayınları, İstanbul.

http://www3.tcmb.gov.tr

https://tkbb.org.tr

İyibozkurt, Erol (2001) Uluslararası İktisat, Ezgi Kitapevi, Bursa.

Özsoy, M. Şerafettin (2012) Sağlam Bankacılık Modeli ile Katılım Bankacılığına Giriş, Kuveyt Türk Katılım Bankası A.Ş. Yayınları, Birinci Baskı, İstanbul.

Tunç, Hüseyin (2010) Katılım Bankacılığı Felsefesi, Teorisi ve Türkiye Uygulaması, Nesil Yayınları, İstanbul.

Udovitch, Abraham L. (2019) Orta Çağ İslam Dünyasında Ortaklık ve Kar,(Çev. İsmail Bektaş), Albaraka Yayınları, İstanbul. 